\title{
Adult Delinquency and Victimization: A Test of Differential Association Theory with New Data
}

\author{
Shah Alam \\ West Virginia University, sa0215@mix.wvu.edu
}

Follow this and additional works at: https://researchrepository.wvu.edu/etd

Part of the Criminology Commons, Gender and Sexuality Commons, Quantitative, Qualitative, Comparative, and Historical Methodologies Commons, and the Social Control, Law, Crime, and Deviance Commons

\section{Recommended Citation}

Alam, Shah, "Adult Delinquency and Victimization: A Test of Differential Association Theory with New Data" (2021). Graduate Theses, Dissertations, and Problem Reports. 8030.

https://researchrepository.wvu.edu/etd/8030

This Thesis is protected by copyright and/or related rights. It has been brought to you by the The Research Repository @ WVU with permission from the rights-holder(s). You are free to use this Thesis in any way that is permitted by the copyright and related rights legislation that applies to your use. For other uses you must obtain permission from the rights-holder(s) directly, unless additional rights are indicated by a Creative Commons license in the record and/ or on the work itself. This Thesis has been accepted for inclusion in WVU Graduate Theses, Dissertations, and Problem Reports collection by an authorized administrator of The Research Repository @ WVU. For more information, please contact researchrepository@mail.wvu.edu. 
Graduate Theses, Dissertations, and Problem Reports

2021

Adult Delinquency and Victimization: A Test of Differential Association Theory with New Data

Shah Alam

Follow this and additional works at: https://researchrepository.wvu.edu/etd

Part of the Criminology Commons, Gender and Sexuality Commons, Quantitative, Qualitative, Comparative, and Historical Methodologies Commons, and the Social Control, Law, Crime, and Deviance Commons 
Adult Delinquency and Victimization: A Test of Differential Association Theory with New Data

Shah Alam

Thesis submitted to the Eberly College of Arts and Sciences at West Virginia University in partial fulfillment of the requirements for the degree of

Master of Arts

in Sociology

Crime concentration

Corey Colyer, Ph.D., Chair

Katie Corcoran, Ph.D.

Chris Scheitle, Ph.D.

Department of Sociology and Anthropology

Morgantown, West Virginia

2021

Key words: Delinquency, Victimization, Adult, Gender, Differential Association, Marijuana, Prescription Pain Medication, Assault, Property Crime, WVSS 2020.

Copyright 2021 Shah Alam 


\begin{abstract}
Adult Delinquency and Victimization: A Test of Differential Association Theory with New Data
\end{abstract}

\begin{abstract}
Shah Alam
The theory of differential association applies not only to adolescent people but also to the adult population. A lot of studies tested this theory on delinquent behavior but tests on victimization are rare. Using West Virginia Social Survey 2020 data, this study finds that there is an association between having delinquent friends and learning of self-delinquency in the adult population. It also reports that self-victimization can be predicted with having delinquent friends. The highest probability of victimization is twice for people for having pain medication misuser friends than of people having marijuana user friends. But self-delinquent behaviors do not report to mediate the association between having delinquent friends and victimization for adults as opposed to the adolescent population. Moreover, results indicate that the victimization for having delinquent friends is most predicted for males than females. But the association with peer delinquency and self-delinquency does not vary across gender. As of interest, nevermarried people compared to married people reported learning marijuana use but not prescription pain medication misuse because of association with delinquent friends.
\end{abstract}




\section{Table of Contents}

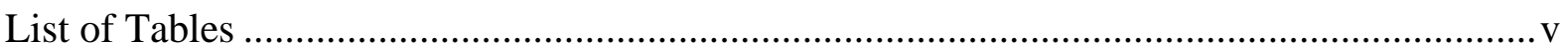



Introduction:

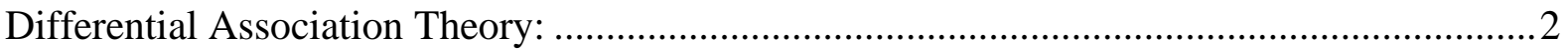

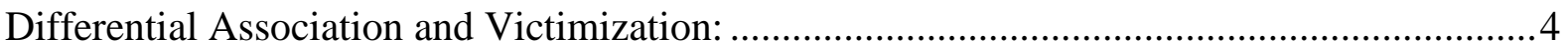

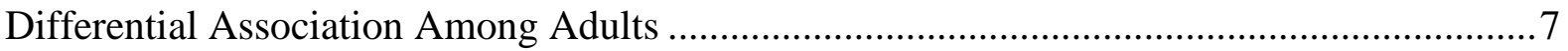

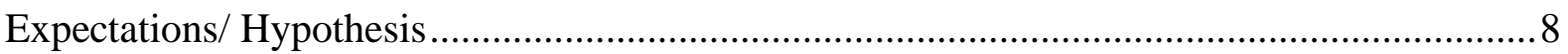



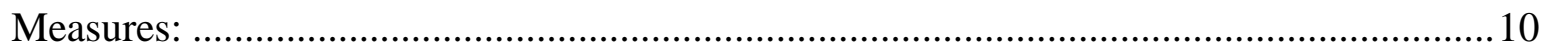

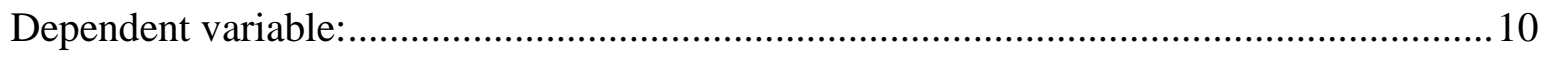

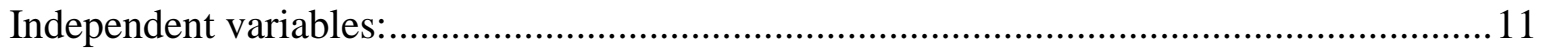



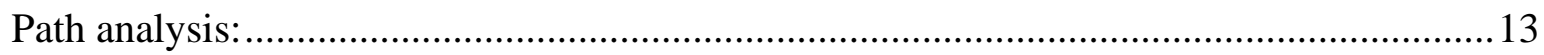

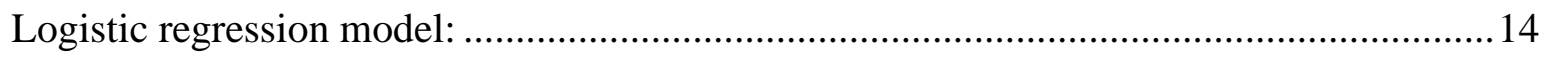

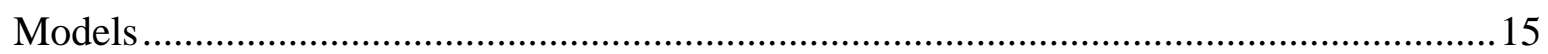



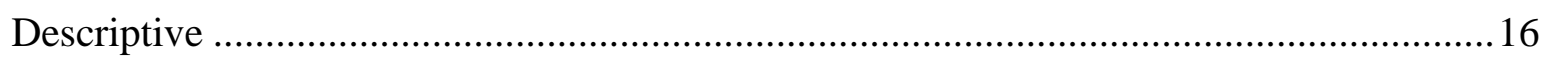

Predicting self-delinquency with peer delinquency and control measures (OLS) ............... 19

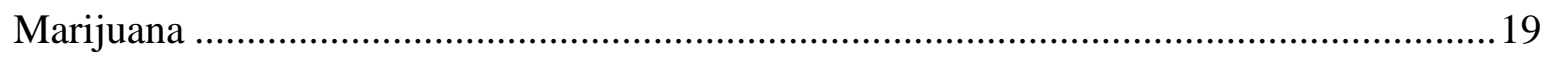

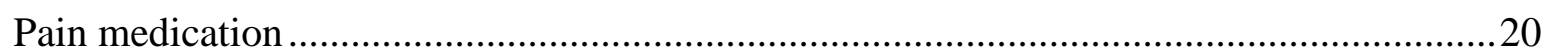


Predicting victimization with self-delinquency and control measures (Logistic Table 3)...22



Self-misuse of prescription pain medication and victimization ........................................24

Predicting victimization with peer delinquency and control measures (Logistic Table 4).. 24



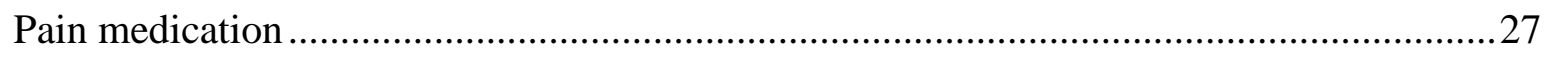

Predicting victimization with peer delinquency and self-delinquency and control measures

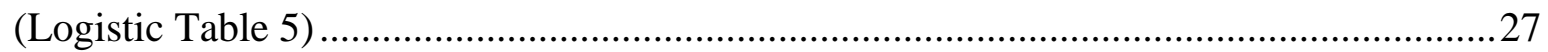

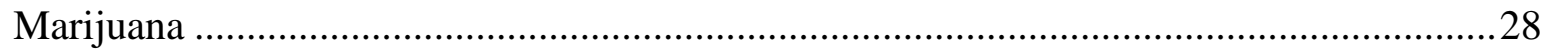

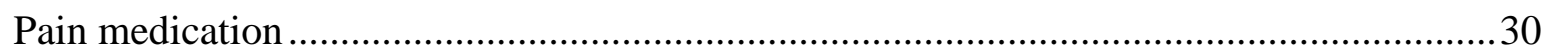





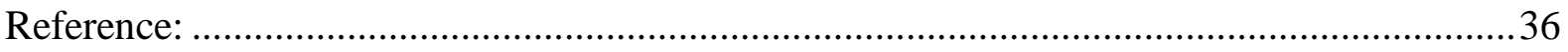




\section{List of Tables}

Table 1. Descriptive statistics

Table 2. OLS of Predicting self-delinquency with peer delinquency and control measures ..21

Table 3. Logistic regression of predicting victimization with self-delinquency .23

Table 4. Logistic regression of predicting victimization with peer delinquency .25

Table 5. Logistic regression of predicting victimization with both peer delinquency and selfdelinquency . .29 


\section{List of Figures}

Figure A: Conceptual Framework of Victimization for Having Delinquent Friends .14

Fig 1: Model 1, Predicting Self-delinquency .31

Fig 2: Model 2, Predicting Victimization with Self-delinquency..... .31

Fig 3: Model 3, Predicting Victimization with Peer Delinquency. 32

Fig 4: Model 4, Predicting Victimization with Peer Delinquency and Self-delinquency 32 


\section{Introduction:}

The theory of differential association is well-established and widely tested in the field of criminology. Almost all the studies that used differential association theory are based on the adolescent population. Studies of testing differential association theory on the adult population are rare. In this study, I have tested this theory on the adult population. A few studies tested differential association theory that measured delinquency and criminal behavior to predict learning of those behaviors, for example, drug use and other substance use among the adult population. But I found no studies testing differential association that considered victimization as an outcome of delinquent behaviors. So, this study aims to test the applicability of differential association theory in adult victimization research. For this purpose, we used assault, property theft to conceptualize the victimization. As predicting variable, I adopted the use of marijuana and misuse of prescription pain medication as delinquent behaviors. Sociodemographic conditions like age, gender, education, marital status, and racial identity have been used as control measures. Also, gender differences in learning delinquent behaviors and adult victimization have been examined with special attention that I wanted to explain the victimization based on gender identity.

Additionally, most studies I found which tested differential association theory with the adult population are approximately three decades old. I wanted to track the changes in the differential association theory research in the last few decades. Therefore, in this study, I used the most recent West Virginia Social Survey (WVSS) 2020 data to demonstrate the applicability of differential association theory for adult victimization. This data is weighted to match national census estimates. So, I am confident that the measures for the differential association I adopted from the WVSS 2020 data are representative and reliable to conduct this kind of study. 


\section{Differential Association Theory:}

Edwin Sutherland first introduced the theory of differential association in the 'Principles of Criminology' in 1939. Sutherland provided nine propositions of the differential association theory to explain delinquency (Kauzlarich and Barlow 2009). He argued that criminal behavior is learned, and this learning is through interaction with other persons (Cressey 1960). The intimacy with the personal peer group facilitates the principal part of learning. This third proposition of Sutherland's differential association theory will be the basis of the explanation of adult delinquency and victimization.

Sutherland's differential association theory has some ambiguities like 'definitions' favorable to deviance, and 'violations' that lead later researchers to interpret differently (Jackson, Tittle, and Burke 1986). Some interpreted as direct effects of differential associations, some interpreted as indirect effects, or some interpreted as both. This study sought to clarify the causal structure and mediating links of the theory. Moreover, I attempted to see whether the differential association theory is crime specific or general crime and what are the ranges of offenses differential association covers? From this perspective, I included victimization to explore the application of the theory.

Though Sutherland first formally introduced the theory of differential association in the third edition of Principles of Criminology in 1939, it was stated in a previous version of the text (Cressey 1960). After its introduction, the theory was subjected to criticism and tested for its applicability to explain delinquency. For example, in the first statement of the theory, Sutherland argued that individual criminality is learned. A process of differential association with criminal and non-criminal behaviors influence the individual. Sutherland later found errors with the word 'consistency' as it presented a general explanation of criminality and deleted the word 'consistency' in the second statement that appeared in 1947 in the fourth 
edition of Principal of Criminology. Moreover, he deleted the word 'systematic' as it made a problem in interpretation.

In the first two decades of the theory, there were attempts to revise the differential association theory to explain the origin and persistence of delinquent subcultures (Cohen 1955); (Cloward and Ohlin 2013), and to include principles of symbolic interaction and role theory (Cressey 1954; Glaser 1956, 1960; Weinberg, K 1966), and to incorporate principles of social learning (Burgess and Akers 1966; Jeffrey 1965); Akers 1973).

In the third decade of the theory, there were two distinct trends to supplant the theoretical innovation trend (Matsueda 1988). The first trend involved testing the theory to formulate the methods to operationalize the theory's concepts and use its propositions for making hypotheses and using these hypotheses for empirical verification. Secondly, an attempt was made to reject the theory's principles in support of social control or integrated theories (Matsueda 1988). Theoretical critique of differential association theory by Kornhauser (1963) and empirical study supporting social control theory by Hirschi (1969) are notable stimulations in this trend.

This study of testing differential association theory is motivated by the first trend of the third-decade attempts. For this purpose, I operationalized the theory's concepts and propositions to explain learning adult delinquent behaviors and adult victimization. For testing the empirical applicability of the theory on the adult population, I adopted adult delinquent behaviors i.e., marijuana use and misusing prescription pain medication. Moreover, I extend the theory's propositions to hypothesize the adult victimhood for having adult delinquent friends. Hence, adult assault occurrences and property theft were adopted to measure adult victimization. 
Approximately fifty years after introducing differential association, Matsueda argued that Sutherland intended to offer a universal explanation of crime, making some concrete conditions connected with crime (Matsueda 1988). Sutherland's attempt to formulate the methodology of looking for a universal explanation of crime was a great sign of good science. While the principles and the orientation of the theory are basically sound, the explanation of those abstract mechanisms needs much work to make more concrete for explaining delinquency and crime. This study is an attempt to contribute to this process.

\section{Differential Association and Victimization:}

Differential association theory argues that individual's delinquent behavior depends on their association with a group of delinquent peers. If a group of delinquent friends with whom an individual hangs out, recommends, and encourages to do some specific delinquent behaviors, individuals tend to commit those delinquent behaviors. Individuals gradually observes that the group usually commit delinquent behaviors and they face no problems with that. Also, the group may be committed to being helping if there is any problem for the individual. This is aligned with the differential association theory propositions that individual learns the technique of delinquent behavior that are favorable to violation of legal codes (Cressey 1960). This proposition of differential association theory can explain adult victimization as well. As an individual is encouraged by the delinquent friends to do delinquent behavior that is favorable to violation of legal codes, they can learn to do assault and property theft as well. These assaulting and property theft may turn themselves as a victim of the same crime, because if an individual of a group assault someone of another group, there may be revenge crime that makes the first assaulter as victim in turn.

Studies evidence that the amount of exposure and contact with delinquent peers increases victimization (Beaver 2011). Association with delinquent peers can make an 
individual into a delinquent person. Also, delinquent peers can turn into offenders that can encourage an individual to be an offender. This turning of that individual may increase the chances of self-victimization as offenders frequently end up being victims of assault by others. As a result, traditional criminological theories have been extended to describe victimization in recent times. For example, the extension of Anderson's (1999) code of streets (Stewart, Schreck, and Simons 2006), Gottfredson and Hirschi's (1990) general theory of crime (Schreck 1999), and various adaptions of social learning theory (Fox, Nobles, and Akers 2011; Gover, Kaukinen, and Fox 2008; Jennings et al. 2011) to explain different forms of victimization are notable.

Differential association theory asserts that an individual learns criminal and noncriminal behavior through interaction with the peer group. For describing delinquency, we stress learning delinquent behavior. So, an individual can become a delinquent through learning the techniques of doing delinquent behaviors. After learning the techniques, an individual may involve in illegal activities like assault and property theft. Oftentimes, newly inducted delinquents apply those learned behaviors to other peers of their group or out of their group. For instance, a new member of a delinquent group may assault other members of their group or other people out of their group to exercise those learned behaviors. So, there are victimization occurrences, and the assaulter or the property thief may also become a victim of the same delinquent behaviors. Moreover, often there is counter-assault and property crime as revenge action.

There are always a few members of a delinquent group who might be the offender or may assault or abuse physically others (Schreck, Wright, and Miller 2002). In return, there would be reciprocal attacks on the offenders. So, offenders become victims of their own action. Thus, there is a reciprocity of characteristics of the offender and victims frequently (Mustaine and Tewksbury 2000). The characteristics of these victims are different than regular criminal 
victims of mugging, cheating, or any other regular crimes. Learning and applying techniques of delinquency after being associated with fellow delinquents is the cause of victimization here. Thus, delinquents and victims carry similar characteristics because of association with delinquent peers. Therefore, victimization can be explained by the propositions of differential association theory (Zavala, Spohn, and Alarid 2019). The association of having delinquent peers with victimization is mediated through self-delinquency behavior here.

Differential association theory may also explain the gender gap in that males have more delinquent peers than females (Mears, Ploeger, and Warr 1998). There is a victimization gap based on gender that females are less likely to be the victim as usually, they do not engage in the high risky lifestyles, and thus they do not provide more opportunities to the motivated offenders (Lauritsen, Sampson, and Laub 1991). Moreover, studies constantly show that females are less likely than males to be involved in serious delinquent behavior. So, the chance of male victimization is higher than of female victimization. As there is reciprocity of characteristics of offender and victims and the correlates of offending and the correlates of victimization are the same. So, more association with delinquent peers increases the risk of victimization. As females are not in a situation to reciprocate the characteristics of offenders and victims, they are less likely to be the victim as well.

The type of peers and friendship characteristics are more important than simply having any delinquent peers for higher risk of victimization (Schreck, Stewart, and Fisher 2006). Due to the network density that is the number of members in a group, network centrality holding positions in the group, and popularity, the likelihood of occurring delinquency and victimization is higher than only having random delinquent peers (Haynie 2001). For instance, if strong cohesion among peers is present, once an individual has a central position in the group and individuals have popular consent for their actions, delinquency and victimization can happen rather than just having delinquent friends. 


\section{Differential Association Among Adults}

The theory of differential association has been used as the basis of some theoretical explanations of delinquency and crime, including the general theory of crime. Since its introduction differential association has been tested empirically to examine its applicability to the broader explanation of delinquency and crime. Almost all empirical studies have employed delinquency and peer association among adolescents. Rare studies are found that employed victimization and peer association among adults.

In the 1980s, a study was conducted on the adult population to measure drug use and friend's association. Dull's study found that the greater number of close friends who use drugs, the more likely an adult will also use drugs (Dull 1983). His findings evidence strong support for extending the usefulness of differential association to explain drug use among the adult population. This current study has been stimulated from the findings of Dull's study to test differential association among the adult population. Moreover, Dull used the Texas crime poll 1981 data which is around four decades old. This current study used the most recent data from West Virginia Social Survey (WVSS) 2020, which is conducted on the adult population.

Studies on testing differential association on substance use of youth population also motivated the current study. The selection hypothesis is a stronger predictor of the correlation between substance use and differential association (Rebellon 2012). As the current study was conducted on the adult population, the selection process relatively important than socialization to predict the learning of delinquent behaviors here. 


\section{Expectations/ Hypothesis}

Broadly, the purpose of the study is to explore the applicability of the differential association theory in the adult population, more specifically in adult delinquency and adult victimization. To achieve the purpose, I made the following hypothesis:

$\mathrm{H} 1$ : There is an association between victimization and having delinquent peers.

$\mathrm{H} 2$ : The association between victimization and having delinquent peers is mediated thorough self-delinquency.

H3: Male is reported more victimization than female victimization.

\section{Methods}

Data

This study has used West Virginia Social Survey 2020 dataset to test the differential association theory in adult victimization. West Virginia Social Survey is the first of its kind in the state of West Virginia conducted in 2020. Department of Sociology and Anthropology, West Virginia University has funded the survey. A mail-in survey was conducted between March 2020 and April 2020 to collect data from 55 counties of the state. A total of 4950 households has been selected to send the surveys. A total of 1,888 responses were received, which constitutes a $38.1 \%$ response rate. Respondents are all adults aged between 18 to 80 or older.

There are several reasons behind using West Virginia social survey 2020 data. First, the goal of the study is to explore testability of the Sutherland's differential association theory on the adult population. As stated earlier, Sutherland presented the theory based on the adolescent population. From 1939, the year the theory was introduced, there were approximately hundreds of empirical tests of this theory. Most of the testing was on adolescent 
populations. Only a handful of studies were conducted on the adult population to test the differential association theory. Given that the WVSS collected data from the adult population aged 18 to 80 or older, West Virginia social survey data is appropriate to test the theory of differential association.

Second, As noted above, a handful of studies were conducted on the adult population to test the theory of differential association theory. The most recent data regarding differential association theory available are on adolescents, for example, Gang Resistance Education and Training (GREAT) data of 2006-2011. Publicly available data I find testing differential association theory on adult population is in 1992 latest. So, West Virginia Social Survey data is the most recent data to which the researcher has access.

Third, the dependent variable of the study is whether respondents have been victimized by assault, property crime, and other crimes or not. The West Virginia social survey data contains questions that directly answer the predicting variable of the study, which is victimization. Consequently, this is another reason for using West Virginia social survey data.

Fourth, this study considered the use of marijuana and misuse of pain medication as the indicator of delinquent behavior. West Virginia social survey data contains questions on these two delinquent behaviors. In WVSS, there are questions that were asked to respondents whether they used marijuana and frequencies of use. The same kind of questions was asked about misusing pain medication. Similar questions were asked about their close friends, answers to these questions are central to determine the association between respondents and their delinquent friends. So, based on the information pertinent to study variables, WVSS data is fitting to use for this study. As a note, In West Virginia marijuana is not decriminalized. Medical marijuana is permitted but patients must obtain physician's certification to use it for 
medicinal purposes. So, using marijuana and misusing pain medication are two kinds of delinquent behaviors that are considered in the study.

Lastly, West Virginia Social Survey collected data from 1,888 respondents of all 55 counties of the state of West Virginia. The data were weighted to make every county representative in the whole sample. The weighting process considered age, gender, race, education, marital status, and population per county with census population data.

\section{Measures:}

\section{Dependent variable:}

A person who reported victim of assault, property crime, or other crime has been considered for victimization variable. Question no. 56 of the WVSS contains elements that can fit the victimization variable. This question is 'Have you personally, a member of your immediate family, a member of your extended family, a close personal friend, or an acquaintance experienced the following in the last 12 months? The responses are $1=$ Homelessness, $2=$ assault, $3=$ property crime, $4=$ other type of crime, $5=$ arrest, and $6=$ not having food. To operationalize 'victimization' this study will consider three experiences (assault, property crime, and other crime) to create a dependent variable that is victimization. A binary response variable will be constructed as reported victim equal to $Y E S=1$, not reported to victim equal to $N O=0$. Respondents who checked the box for assault, property crime, and other crimes will be considered in the YES=1 category, and those who did not check will be categorized in the $\mathrm{NO}=0$ category. There are 84 self-reported observations who said they experienced assault, property crime, and other types of crime. 


\section{Independent variables:}

1. Gender: recoded variable 'female' where $0=$ male and $1=$ female who responded to have experience of assault, property crime, and other crime.

2. Association with delinquent peers: to observe an association with delinquent peers, I have considered several questions:

a. How many close friends of yours have used marijuana in the last 12 months? In the WVSS, there are no direct questions like this. So, I considered question no. 55_4 which asked responded how frequently a close personal friend of yours used marijuana in the last 12 months? There are 7 responses which are $1=$ never, $2=$ once or twice a year, $3=$ several times a year, $4=$ once a month, $5=2-3$ times a month, 6=weekly, $7=$ several times a week. I have considered all 7 responses to measure the magnitude of association with delinquent peers.

b. How many close friends of yours have misused prescription pain medication in the last 12 months? In the WVSS, there are no direct questions like this also. So, I considered question no. 52_4 which asked respondents how frequently a close personal friend of yours misused prescription pain medication in the last 12 months? There are 7 responses which are $1=$ never, $2=$ once or twice a year, $3=$ several times a year, $4=$ once a month, 5=2-3 times a month, $6=$ weekly, $7=$ several times a week. Here I have considered all 7 responses to measure the magnitude of association with delinquent peers as well

3. To measure self-delinquency, I consider the self-reported use of marijuana. And selfreported misuse of pain medication.

c. Question 55_1 of WVSS asked how frequently respondents personally used marijuana in the last 12 months? Seven responses were recorded where $1=$ never, $2=$ once or twice a year, $3=$ several times a year, $4=$ once a month, $5=2-3$ times a 
month, $6=$ weekly, $7=$ several times a week. To measure the frequency of selfdelinquency these all seven responses will be considered.

d. Question 52_1 of WVSS asked how frequently respondents personally misused prescription pain medication in the last 12 months? Seven responses were recorded where $1=$ never, $2=$ once or twice a year, $3=$ several times a year, $4=$ once a month, 5=2-3 times a month, $6=$ weekly, $7=$ several times a week. To measure the frequency of self-delinquency these all seven responses will be considered as well.

\section{Analysis tool/techniques:}

The nature of the relationship of the variables in the study and the availability of techniques drive me to use ordinary least squares (OLS) and logistic regression to examine the mediating effects of self-delinquency on victimization. To test the differential association theory, I argue that there is an association between having delinquent friends and the victimization of respondents, meaning hanging out with delinquent friends leads to learning delinquent behaviors that ultimately lead to victimization. But the association between these two variables is not direct, rather the association is mediated through the self-delinquency variable. In other words, the association between having delinquent friends and victimization is indirect. For instance, an individual who reported to be a victim of assault, property crime, or other crime also reported to have delinquent friends, but having delinquent friends is not the only cause of their victimization. Self-delinquency plays the role of being the victim. For example, through hanging out with delinquent friends, individuals learn delinquent behaviors and, they apply those delinquent behaviors to other people. Those victims counterattack the individual, thus self-delinquency leads the individual to be a victim. In other words. after learning delinquent behavior, they may offend others, who in return will offend the first offender as a revengeful behavior. Thus, they can exchange the 'victim' identity as reciprocal. 
Alternatively, there may be victimization for only having an association with delinquent friends. If we take this argument it will be more aligned with routine activity theory which is not the goal of this study. Rather, I argue that self-delinquency that is derived from hanging out with delinquent friends is the direct cause of self-victimization, having delinquent friends is an indirect predictor of the victimization in this case. I am focusing on the following propositions of differential association theory that delinquency is learned, and it is learned through association with delinquent friends. After learning techniques for committing delinquency that is favorable to breaking the law, an individual commits that delinquency because they already know how to escape from legal punishment. This self-delinquency leads an individual to be a victim. If I control the self-delinquency variable, the association between having delinquent friends and victimization will not be significant. So, the pathway for analysis stands like this: Having delinquent friends $\rightarrow$ Self-delinquency $\rightarrow$ Victimization. To explain the pathway, I used path analysis.

\section{Path analysis:}

Theoretically, path analysis is an apprehending technique to understand the relationship I am trying to make. In the path analysis, I can take several paths like Path $\mathrm{A}, \mathrm{B}, \mathrm{C}$, and $\mathrm{AB}$. Having delinquent friends $\rightarrow$ victimization: path $\mathrm{C}$, having delinquent friends $\rightarrow$ selfdelinquency $=$ path $\mathrm{A}$, self-delinquency $\rightarrow$ victimization $=$ path $\mathrm{B}$, and having delinquent friends $\rightarrow$ Self-delinquency $\rightarrow$ victimization $=$ path $\mathrm{AB}$. Among the paths, analysis of path $\mathrm{AB}$ is essential to examine the mediating effects of self-delinquency. So, path analysis will be used to examine the association between having delinquent friends, self-delinquency, and victimization in this study. 


\section{Logistic regression model:}

Logistic regression analysis model also has been used because of the study's nature and type of relationship between variables. In the ordinary regression models, we can find only a linear relationship but in the logistic regression model, we are able to find an $\mathrm{S}$ curved relationship between predictor and outcome which is a crucial part of the study. In this study, I have a predictor of victimization that is having delinquent friends, but this prediction can be made through a mediating variable that is self-delinquency. In the ordinary least square regression model, I am not able to predict the likelihood of victimization, as it expresses linear outcomes. So, I used the logistic regression model to find the likelihood of victimization for having delinquent friends. Moreover, I essentially want to see the mediating effect of selfdelinquency to victimization for having delinquent friends on victimization. To do this the following is a conceptual framework of the study.

\section{Figure A: Conceptual Framework of Victimization for Having Delinquent Friends}

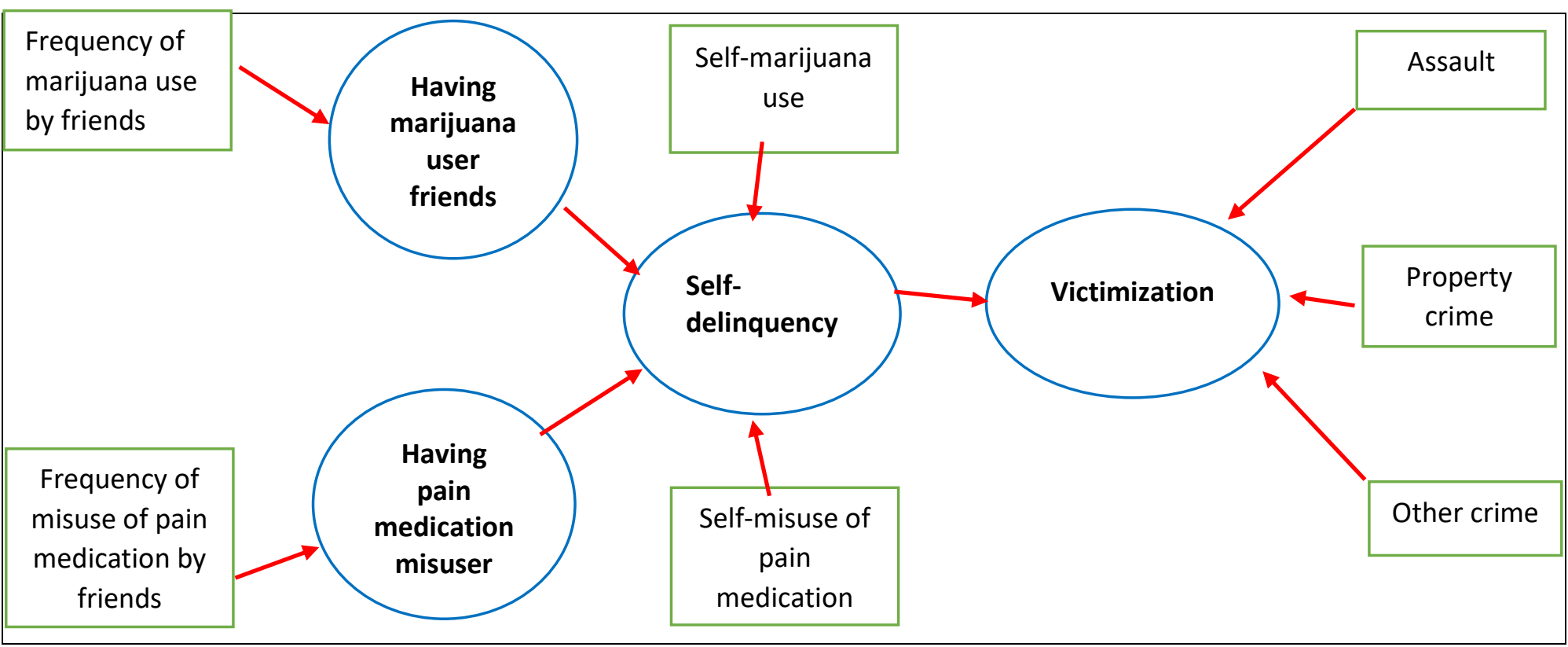




\section{Models}

Primarily I proposed four key models to examine all three hypotheses. Model 1 has been used to predict self-delinquent behaviors for having delinquent peers. Model 2 has been used to predict the likelihood of victimization for self-delinquent behaviors. Model 3 has been used to predict the likelihood of victimization for having delinquent friends. Lastly, model 4 is used to explore mediating effect of self-delinquency in victimization for having delinquent friends. In other words, the association between having delinquent friends and victimization mediated through self-delinquency.

Model 1.a: Predicting self-use of marijuana with peer use of marijuana and control measures

Model 1.b: Predicting self-misuse of pain medication with peer misuse of pain medication and control measures

Model 2.a: predicting victimization with self-use of marijuana and control measures

Model 2.b: predicting victimization with self-misuse of prescription pain medication and control measures

Model 3.a: predicting victimization with peer marijuana and control measures

Model 3.b: predicting victimization with peer prescription pain medication misuse and control measures

Model 4.a: predicting victimization with both peer marijuana and self-marijuana use and control measures

Model 4.b: predicting victimization with both peer prescription pain medication misuse and self-misuse of prescription pain medication and control measures 
Additionally, model 3 examined hypothesis 1 that is the association between having delinquent friends and victimization. Model 4 has examined hypothesis 2 that the association between victimization and having delinquent friends is mediated through self-delinquency. In all four models, I used the same control variables i.e. age, gender, education level, marital status, and racial identity. In model 4, I wanted to see if there is a difference in the predictability of self-delinquency and peer delinquency to predict victimization. I expected that the association between having delinquent friends and victimization will not be significant if selfdelinquency is controlled. But the association between having delinquent friends and victimization is still significant independent of self-delinquency, a mediating variable. Hypothesis 3 that is the difference of victimization across gender is explored in models 2, 3 and model 4. In all the models, I examined the difference between male and female delinquency and victimization. In these models, I hypothesize that males will have more marijuana and pain medication misuser friends than females. Consequently, learning of using marijuana and misuse of pain medication will be greater for males than a female that will lead them to be more victimized than females.

\section{Results:}

\section{Descriptive}

The data used here are from the West Virginia social survey (WVSS) that represents a sample of 1888 from all fifty-five counties of the state. People are dominantly white which constitutes $96.88 \%$ and $3.13 \%$ are non-white. The age of respondents varies from 18 to 80 and older. There are 8 categories of age: $18-24=1.23 \%, 25-29=1.87 \%, 30-39=7.17 \%, 40-$ $49=11.07 \%, 50-59=18.88 \%, 60-69=27.91 \%, 70-79=21.98 \%$, and 80 or older $=9.89 \%$. approximately $79 \%$ of the population are aged above 50 years old, where $60-69$ category is the dominant one $(27.91 \%)$. On the contrary, only $21 \%$ population falls between 18 and 49 years 
old, where few people fall under the young adult category (3.1\% between 18 and 29). This characteristic of the sample is a strong element of the study as I am testing Sutherland's differential association theory on the adult population which he originally proposed for the adolescent population.

The gender construction of the sample is $42.05 \%$ male and $57.95 \%$ are female. This is another important element of the sample that align with one of the three hypotheses of the study. I hypothesized that males will be more victimized than females as a result of association with delinquent peers. Approximately $57.05 \%$ of respondents are married while $17.31 \%$ are divorced or separated, $16.08 \%$ are widowed and $9.56 \%$ respondents were never married. To note about education level, only $41.18 \%$ are high school graduates, some $17.65 \%$ have some college education rest of the respondents varies from less than high school to the doctorate.

Table 1. Descriptive statistics

\begin{tabular}{|c|c|c|}
\hline & Count & Mean or percentage \\
\hline \multicolumn{3}{|l|}{$\begin{array}{l}\text { Reported for the victimization of } \\
\text { assault, property crime, and other } \\
\text { crime }\end{array}$} \\
\hline Not victim & 1804 & $95.55 \%$ \\
\hline Victim & 84 & $4.45 \%$ \\
\hline \multicolumn{3}{|l|}{ Peer marijuana use } \\
\hline never & 1255 & $75.19 \%$ \\
\hline Once or twice a year & 63 & $3.77 \%$ \\
\hline Several times a year & 70 & $4.19 \%$ \\
\hline Once a month & 21 & $1.26 \%$ \\
\hline 2-3 times a month & 43 & $2.58 \%$ \\
\hline Weekly & 67 & $4.01 \%$ \\
\hline Several times a week & 150 & $8.99 \%$ \\
\hline \multicolumn{3}{|l|}{ Self- marijuana use } \\
\hline never & 1678 & $91.00 \%$ \\
\hline Once or twice a year & 50 & $2.71 \%$ \\
\hline Several times a year & 28 & $1.52 \%$ \\
\hline Once a month & 6 & $0.33 \%$ \\
\hline 2-3 times a month & 13 & $0.70 \%$ \\
\hline Weekly & 14 & $0.76 \%$ \\
\hline Several times a week & 55 & $2.98 \%$ \\
\hline \multicolumn{3}{|l|}{ Peer pain medication misuse } \\
\hline never & 1520 & $88.94 \%$ \\
\hline
\end{tabular}




\begin{tabular}{|c|c|c|}
\hline Once or twice a year & 49 & $2.87 \%$ \\
\hline Several times a year & 50 & $2.93 \%$ \\
\hline Once a month & 9 & $0.53 \%$ \\
\hline 2-3 times a month & 13 & $0.76 \%$ \\
\hline Weekly & 22 & $1.29 \%$ \\
\hline Several times a week & 46 & $2.69 \%$ \\
\hline \multicolumn{3}{|l|}{ Self-pain medication misuse } \\
\hline never & 1806 & $98.74 \%$ \\
\hline Once or twice a year & 11 & $0.60 \%$ \\
\hline Several times a year & 3 & $0.16 \%$ \\
\hline Once a month & 0 & $0.00 \%$ \\
\hline 2-3 times a month & 3 & $0.16 \%$ \\
\hline Weekly & 3 & $0.16 \%$ \\
\hline Several times a week & 3 & $0.16 \%$ \\
\hline \multicolumn{3}{|l|}{ Age categories } \\
\hline $18-24$ & 23 & $1.23 \%$ \\
\hline $25-29$ & 35 & $1.87 \%$ \\
\hline $30-39$ & 134 & $7.17 \%$ \\
\hline $40-49$ & 207 & $11.07 \%$ \\
\hline $50-59$ & 353 & $18.88 \%$ \\
\hline $60-69$ & 522 & $27.91 \%$ \\
\hline $70-79$ & 411 & $21.98 \%$ \\
\hline 80 or older & 185 & $9.89 \%$ \\
\hline \multicolumn{3}{|l|}{ Gender } \\
\hline Male & 786 & $42.05 \%$ \\
\hline Female & 1083 & $57.95 \%$ \\
\hline \multicolumn{3}{|l|}{ Race } \\
\hline White & 1829 & $96.88 \%$ \\
\hline Non-white (Black, Asian, other) & 59 & $3.13 \%$ \\
\hline \multicolumn{3}{|l|}{ Education } \\
\hline Less than HS & 56 & $3.05 \%$ \\
\hline Some HS & 105 & $5.72 \%$ \\
\hline HS Graduate & 756 & $41.18 \%$ \\
\hline Some College & 324 & $17.65 \%$ \\
\hline Associate Degree & 160 & $8.71 \%$ \\
\hline Bachelors & 251 & $13.67 \%$ \\
\hline Masters & 148 & $8.06 \%$ \\
\hline Professional & 20 & $1.09 \%$ \\
\hline Doctorate & 16 & $0.87 \%$ \\
\hline \multicolumn{3}{|l|}{ Marital status } \\
\hline Married & 1068 & $57.05 \%$ \\
\hline Divorced or separated & 324 & $17.31 \%$ \\
\hline Widowed & 301 & $16.08 \%$ \\
\hline Never Married & 179 & $9.56 \%$ \\
\hline
\end{tabular}

WVSS 2020. $\mathrm{N}=1888$ 


\section{Predicting self-delinquency with peer delinquency and control measures (OLS)}

In model 1, I used ordinary least square (OLS) regression to explain how peer delinquency with other control measures can predict self-delinquency. To define selfdelinquency, I conceive the use of marijuana and misuse of prescription pain medication of the respondents. Both delinquent behaviors had response varies from 1 to 7 where 1 represents never use and 7 represents highest uses. The following is the description of findings based on two separate delinquent behaviors.

\section{Marijuana}

In table 2, model 1.a suggests that association with marijuana user friends can predict self-marijuana use. Coefficients 0.320 imply that one-unit change in the association with marijuana user friends increases 0.320 in the prediction of self-marijuana use. The coefficients represent a slightly weak relationship between friend's marijuana use and self-marijuana use.

Having friends who never used marijuana will predict an increase of self-marijuana use by 0.320 . Similarly having friends who use marijuana once or twice a year will increase selfmarijuana use by 0.320 from the previous level. Consequently, respondents associated with friends who use marijuana several times a week will increase self-marijuana use to coefficients to 2.93

This result is statistically significant at $p<0.001$ which means that the evidence favorable to the association is very strong. In reference to married persons, divorced or separated and never married persons reported to use more marijuana for having marijuana user friends. Their coefficients are 0.109 and 0.377 respectively but only coefficients of never married person is statistically significant. Compare to married people, never married persons reported a stronger association at $p<0.001$. So, it can be concluded that never married persons tend to use more marijuana while married persons use less. It is assumed that married persons 
are busy or having a good time in married life that they do not feel using marijuana. On the other hand, non-married persons may have a hard time and struggling being alone which led them to hang out with people who use marijuana to have some company. This hanging out may have led them to start using marijuana. Though the study does not include other measures that could have explained other causes of hanging out of non-married persons with marijuana user friends. Gender, age, race, and education levels all are reported as not significant.

\section{Pain medication}

Model 1.b of table 2 represents predicting self-misuse of prescription pain medication for having an association with prescription pain medication misuser friends. The coefficient 0.051 is statistically significant at $p<0.001$ which signifies strong evidence favoring association between behaviors of these two groups of the population. In other words, respondents having friends who misuse prescription pain medication once or twice a year increase chance of self-misusing pain medication by 0.051 . But the association is very weak.

One other interesting finding is that persons who are in older group, have a higher level of education tend to have a negative association with prescription pain medication misuse. The results are not statistically significant though. Another interesting finding is the racial difference in predicting self-misuse of prescription pain medication. In reference to the white population, the non-white population reported having a significant association with misusing pain medication due to association with pain medication misuser friends. If I compare both behaviors, this was not the same case in marijuana use behavior. One probable cause of different results between two delinquent behaviors may be non-white population might use pain medication as a substitute for marijuana to avoid marijuana-related criminal offenses. Pain medication may be also easier to buy and use than marijuana especially when there are law 
enforcement matters in the case of marijuana but not with pain medication. All other control measures e.g. gender, age, and marital status reported being not significant.

\begin{tabular}{|c|c|c|}
\hline & $\begin{array}{c}\text { Model 1.a } \\
\text { Self-Marijuana use }\end{array}$ & $\begin{array}{c}\text { Model 1.b } \\
\text { Self-misuse of pain } \\
\text { medication }\end{array}$ \\
\hline \multicolumn{3}{|l|}{ Behavioral } \\
\hline $\begin{array}{l}\text { Peer use of } \\
\text { marijuana }\end{array}$ & $\begin{array}{l}.320 * * * \\
(.013)\end{array}$ & \\
\hline $\begin{array}{l}\text { Peer misuse of } \\
\text { pain medication }\end{array}$ & & $\begin{array}{l}.051 * * * \\
(.007)\end{array}$ \\
\hline \multicolumn{3}{|l|}{ Sociodemographic } \\
\hline \multicolumn{3}{|l|}{$\begin{array}{l}\text { Gender } \\
\text { (Ref. Female) }\end{array}$} \\
\hline Male & $\begin{array}{l}0.011 \\
(.053) \\
\end{array}$ & $\begin{array}{l}-.002 \\
(.015) \\
\end{array}$ \\
\hline Age & $\begin{array}{l}0.007 \\
(.019)\end{array}$ & $\begin{array}{l}-.002 \\
(.005)\end{array}$ \\
\hline Education level & $\begin{array}{l}-.022 \\
(.016)\end{array}$ & $\begin{array}{l}-.006 \\
(.005)\end{array}$ \\
\hline \multicolumn{3}{|l|}{$\begin{array}{l}\text { Race } \\
\text { (Ref. White) }\end{array}$} \\
\hline Non-White & $\begin{array}{c}.097 \\
(.158)\end{array}$ & $\begin{array}{l}.229 * * * \\
(.046)\end{array}$ \\
\hline \multicolumn{3}{|l|}{$\begin{array}{l}\text { Marital status } \\
\text { (Ref. Married) }\end{array}$} \\
\hline Divorced/Separated & $\begin{array}{l}0.109 \\
(.065)\end{array}$ & $\begin{array}{c}.012 \\
(.021) \\
\end{array}$ \\
\hline Widowed & $\begin{array}{c}.022 \\
(.079)\end{array}$ & $\begin{array}{c}.000 \\
(.023)\end{array}$ \\
\hline Never Married & $\begin{array}{l}.377 * * * \\
(.091)\end{array}$ & $\begin{array}{c}.043 \\
(.027)\end{array}$ \\
\hline
\end{tabular}

$* \mathrm{p}<0.05, * * \mathrm{p}<0.01 . * * * \mathrm{p}<0.001$. Parenthesis contains standard errors.

Model 1a: $\mathrm{N}=1596, \mathrm{R}^{2}=0.2971$

Model 1b: $\mathrm{N}=1634 . \mathrm{R}^{2}=0.0583$ 


\section{Predicting victimization with self-delinquency and control measures (Logistic Table 3)}

In table 3, Model 2 represents logistic regression analysis of predicting victimization with self-delinquent behaviors. Use of marijuana and misuse of prescription pain medication is used as delinquent behaviors while the victim of assault, property crime, and other crime considered for conceptualizing victimization. Model 2.a denotes prediction of victimization with marijuana use and prediction of victimization with misuse of prescription pain medication shown by model 2.b.

\section{Self-use of marijuana and victimization}

Model 2.a shows the result for predicting victimization with self-marijuana use. Though the odds ratio of 1.102 indicates the odds of victimization for self-use of marijuana, the result is not significant. Interestingly, the odds of victimization of males for self-marijuana use reports a significant odds ratio. The odds of male being victimized is $76 \%$ greater than odds of female being victimized. The result is significant at $p<0.05$ which signifies a moderately strong association between victimization and gender in terms of marijuana use. Moreover, the odds ratio of age for predicting victimization with marijuana use is 0.82 . The result indicates that in every one category increase in the age groups, the odds of victimization for selfmarijuana use decrease by $18 \%$. So, as people get older, the chance of victimization for selfmarijuana use decreases. The finding is significant at $p<0.05$. 


\begin{tabular}{|c|c|c|}
\hline & $\begin{array}{c}\text { Model 2.a } \\
\text { Victimization with } \\
\text { marijuana use }\end{array}$ & $\begin{array}{c}\text { Model 2.b } \\
\text { Victimization with Pain } \\
\text { medication }\end{array}$ \\
\hline \multicolumn{3}{|l|}{ Behavioral } \\
\hline $\begin{array}{l}\text { Self-use of } \\
\text { marijuana }\end{array}$ & $\begin{array}{l}1.102 \\
(.084)\end{array}$ & \\
\hline $\begin{array}{l}\text { Self-misuse of } \\
\text { pain medication }\end{array}$ & & $\begin{array}{l}1.292 \\
(.238)\end{array}$ \\
\hline \multicolumn{3}{|l|}{ Sociodemographic } \\
\hline \multicolumn{3}{|l|}{$\begin{array}{l}\text { Gender } \\
\text { (Ref. Female) }\end{array}$} \\
\hline Male & $\begin{array}{l}1.763^{*} \\
(.416)\end{array}$ & $\begin{array}{l}1.795^{*} \\
(.421)\end{array}$ \\
\hline Age & $\begin{array}{l}.820^{*} \\
(.069)\end{array}$ & $\begin{array}{l}.825^{*} \\
(.068)\end{array}$ \\
\hline Education level & $\begin{array}{l}.999 \\
(.073)\end{array}$ & $\begin{array}{c}989 \\
(.073)\end{array}$ \\
\hline \multicolumn{3}{|l|}{$\begin{array}{l}\text { Race } \\
\text { (Ref. White) }\end{array}$} \\
\hline Non-White & $\begin{array}{c}1.33 \\
(.814)\end{array}$ & $\begin{array}{l}1.262 \\
(.783)\end{array}$ \\
\hline \multicolumn{3}{|l|}{$\begin{array}{l}\text { Marital status } \\
\text { (Ref. Married) }\end{array}$} \\
\hline Divorced/Separated & $\begin{array}{l}1.338 \\
(.413)\end{array}$ & $\begin{array}{l}1.349 \\
(.411)\end{array}$ \\
\hline Widowed & $\begin{array}{l}1.845 \\
(.640)\end{array}$ & $\begin{array}{l}1.753 \\
(.604)\end{array}$ \\
\hline Never Married & $\begin{array}{c}.962 \\
(.390)\end{array}$ & $\begin{array}{l}1.004 \\
(.406)\end{array}$ \\
\hline
\end{tabular}

$* \mathrm{p}<0.05, * * \mathrm{p}<0.01, * * * \mathrm{p}<0.001$. Coefficients are odds ratio. Parenthesis contains standard errors.

Model 2.a: $\mathrm{N}=1763$, Pseudo $\mathrm{R}^{2}=0.0220$

Model 2.b: $\mathrm{N}=1750$. Pseudo $\mathrm{R}^{2}=0.0209$ 


\section{Self-misuse of prescription pain medication and victimization}

Model 2.b shows an odds ratio of 1.29 for predicting victimization with self-misuse of prescription pain medication. This result indicates every one unit change in the frequency of misusing prescription pain medication, there is a $29 \%$ increase in the odds of victimization but the finding is not significant. On the other hand, gender and age categories report a significant odds ratio for predicting victimization for self-misuse of prescription pain medication. Odds ratio of 1.795 for gender means that the odds of males being victimized is $79 \%$ greater than the odds of female being victimized for misusing prescription pain medication. The finding is significant at $p<0.05$. Moreover, the odds ratio of 0.825 for age indicates the odds of victimization decrease by $18 \%$ for every increase in the age categories and the finding is significant at $p<0.05$.

\section{Predicting victimization with peer delinquency and control measures (Logistic Table 4)}

Table 4 represents logistic regression results for models 3.a and 3.b that is predicting victimization with peer marijuana use and peer misuse of prescription pain medication. The result shows that both two delinquent behaviors can predict respondents' victimization. I am reporting separated results below. 


\begin{tabular}{|c|c|c|}
\hline & $\begin{array}{c}\text { Model 3.a } \\
\text { Victimization with } \\
\text { marijuana use }\end{array}$ & $\begin{array}{c}\text { Model 3.b } \\
\text { Victimization with Pain } \\
\text { medication }\end{array}$ \\
\hline \multicolumn{3}{|l|}{ Behavioral } \\
\hline $\begin{array}{l}\text { Peer use of } \\
\text { marijuana }\end{array}$ & $\begin{array}{l}1.160 * * \\
(.059)\end{array}$ & \\
\hline $\begin{array}{l}\text { Peer misuse of } \\
\text { pain medication }\end{array}$ & & $\begin{array}{l}1.317 * * * \\
(.082)\end{array}$ \\
\hline \multicolumn{3}{|l|}{ Sociodemographic } \\
\hline \multicolumn{3}{|l|}{$\begin{array}{l}\text { Gender } \\
\text { (Ref. Female) }\end{array}$} \\
\hline Male & $\begin{array}{l}1.855^{*} \\
(.463)\end{array}$ & $\begin{array}{l}1.863^{*} \\
(.465)\end{array}$ \\
\hline Age & $\begin{array}{c}.849 \\
(.076)\end{array}$ & $\begin{array}{c}.843 \\
(.075)\end{array}$ \\
\hline Education level & $\begin{array}{c}.992 \\
(.075)\end{array}$ & $\begin{array}{c}.967 \\
(.075)\end{array}$ \\
\hline \multicolumn{3}{|l|}{$\begin{array}{l}\text { Race } \\
\text { (Ref. White) }\end{array}$} \\
\hline Non-White & $\begin{array}{l}1.592 \\
(.987)\end{array}$ & $\begin{array}{c}.968 \\
(.719)\end{array}$ \\
\hline \multicolumn{3}{|l|}{$\begin{array}{l}\text { Marital status } \\
\text { (Ref. Married) }\end{array}$} \\
\hline Divorced/Separated & $\begin{array}{l}1.096 \\
(.360)\end{array}$ & $\begin{array}{l}1.146 \\
(.376)\end{array}$ \\
\hline Widowed & $\begin{array}{l}1.630 \\
(.617)\end{array}$ & $\begin{array}{l}1.692 \\
(.624)\end{array}$ \\
\hline Never Married & $\begin{array}{c}.961 \\
(.394)\end{array}$ & $\begin{array}{l}1.002 \\
(.413)\end{array}$ \\
\hline
\end{tabular}

${ }^{*} \mathrm{p}<0.05, * * \mathrm{p}<0.01, * * * \mathrm{p}<0.001$. Coefficients are odds ratio. Parenthesis contains standard errors.

Model 3.a: $\mathrm{N}=1601$, Pseudo $\mathrm{R}^{2}=0.0352$

Model 3.b: $\mathrm{N}=1636$. Pseudo $\mathrm{R}^{2}=0.0502$ 


\section{Marijuana}

Model 3.a is predicting victimization with peer marijuana use. This means less association with marijuana user friends predict less victimization and more association with marijuana user friends predicts more victimization. In model 3.a, the odds ratio of 1.160 suggests that for every one unit change in the association with marijuana user friends there is a 1.160 odds of victimization. In the other words, respondents having an association with friends who never used marijuana have the odds of victimization by 1.160 . When respondents associated with friends who use marijuana once or twice then there is more increase of odds of victimization. This pattern goes to increase as they increase the level of association with more frequent marijuana user friends. This pattern also means that, if the level of association with the more frequent user of marijuana increases then the odds of victimization also increases. Association with the less frequent user of marijuana means less odds of victimization and association with the more frequent user of marijuana means more odds of victimization. This finding supported our hypothesis that association with delinquent friends can predict victimization. The finding is statistically significant at $p<0.01$.

On the other hand, result from gender variation of victimization reports that male is more victimized than female. The odds ratio of 1.855 for males suggests that the odds of victimization for being male is $85 \%$ greater than the odds of victimization for being female. This also means, for males, more association with more frequent marijuana user friends, reports more odds of victimization for males than females. The association is statistically significant at $p<0.05$

Other control measure like age, education level, race, marital status is not significantly associated with the victimization of respondents. This means, irrespective of age, education, marital status people can be victimized by only having an association with marijuana user friends. 


\section{Pain medication}

Model 3.b in table 4 represents the prediction of victimization with friends' misuse of prescription pain medication. The model suggests that having friends who misuse prescription pain medication is associated with the respondent's victimization. The odds ratio of 1.317 means one unit change in the frequency of having friends who misuse prescription pain medication predict 1.317 odds of victimization of respondents. This meaning hanging out with more prescription pain medication misuser friends can result in more odds of victimization. The finding is statistically significant at $p<0.001$ that suggests a very strong association.

Moreover, the gender variation in the victimization is important in predicting victimization with misuse of prescription pain medication. The result shows that males are reported to be more victimized than females. The odds ratio of 1.863 means that the odds of males being victimized is $86 \%$ greater than the odds of females being victimized for having association with prescription pain misuser friends. This result is statistically significant at $p<0.05$. Other control measures: age, education level, race, and marital status are not statistically significant in this model. The result corroborates the hypothesis that males will report more victimization than females for having an association with misuser of prescription pain medication.

\section{Predicting victimization with peer delinquency and self-delinquency and control measures (Logistic Table 5)}

Table 5 represents the prediction of victimization with peer delinquent behavior and self-delinquent behavior and with control measures. I used marijuana use and prescription pain medication misuse to conceptualize both friend's delinquent behavior and self-delinquent behavior. Respondent's age, gender, education, race, and marital status are used as control measures. Model 4.a and Model 4.b findings suggest that both delinquent behaviors of friends 
can predict victimization. But self-delinquent behavior is not associated with predicting victimization while controlling a friend's delinquent behavior. The findings of both models are described below.

\section{Marijuana}

In model 4.a, I report logistic regression analysis to predict victimization associated with peer marijuana use and self-marijuana use. The odds ratio of 1.171 for peer marijuana use suggests that for every one-unit change in the frequency of friends' use of marijuana, there are 1.171 odds of victimization for respondents. This means more association with more frequent marijuana user friends predicts more odds of victimization. The finding is statistically significant at $p<0.01$ which suggests there is a strong association between having marijuana user friends and victimization. The above result is found while I control for self-marijuana use that also suggests that independent of self-marijuana use, friend's marijuana use can alone predict self-victimization. In model 4.a, the odds ratio of self-marijuana use is 0.977 but it is not statistically significant. This result is not favorable to support part of our hypothesis 2 that the association between victimization and having marijuana user friends will be mediated through self-marijuana use.

The gender variable reports a statistically significant result that is supportive of our hypothesis 3 . The odds ratio of 1.835 for males suggests that the odds of victimization for male is $83 \%$ greater than the odds of victimization for females. All other control variables e.g. age, education level, race, and marital status are not statistically significant to predict victimization. 


\begin{tabular}{|c|c|c|}
\hline & $\begin{array}{c}\text { Model 4.a } \\
\text { Victimization with } \\
\text { marijuana use }\end{array}$ & $\begin{array}{c}\text { Model 4.b } \\
\text { Victimization with Pain } \\
\text { medication }\end{array}$ \\
\hline \multicolumn{3}{|l|}{ Behavioral } \\
\hline $\begin{array}{l}\text { Peer use of } \\
\text { marijuana }\end{array}$ & $\begin{array}{l}1.171 * * \\
(.069)\end{array}$ & \\
\hline $\begin{array}{l}\text { Self-use of } \\
\text { marijuana }\end{array}$ & $\begin{array}{c}.977 \\
(.089) \\
\end{array}$ & \\
\hline $\begin{array}{l}\text { Peer misuse of } \\
\text { pain medication }\end{array}$ & & $\begin{array}{l}1.314^{* * * *} \\
(.085)\end{array}$ \\
\hline $\begin{array}{l}\text { Self-misuse of } \\
\text { pain medication }\end{array}$ & & $\begin{array}{l}1.094 \\
(.243)\end{array}$ \\
\hline \multicolumn{3}{|l|}{ Sociodemographic } \\
\hline \multicolumn{3}{|l|}{$\begin{array}{l}\text { Gender } \\
\text { (Ref. Female) }\end{array}$} \\
\hline Male & $\begin{array}{l}1.835^{*} \\
(.458)\end{array}$ & $\begin{array}{l}1.872 * \\
(.467)\end{array}$ \\
\hline Age & $\begin{array}{c}.851 \\
(.077) \\
\end{array}$ & $\begin{array}{c}.847 \\
(.075) \\
\end{array}$ \\
\hline Education level & $\begin{array}{c}.991 \\
(.075) \\
\end{array}$ & $\begin{array}{c}.968 \\
(.075) \\
\end{array}$ \\
\hline \multicolumn{3}{|l|}{$\begin{array}{l}\text { Race } \\
\text { (Ref. White) }\end{array}$} \\
\hline Non-White & $\begin{array}{c}1.637 \\
(1.016) \\
\end{array}$ & $\begin{array}{r}.936 \\
(.701) \\
\end{array}$ \\
\hline \multicolumn{3}{|l|}{$\begin{array}{l}\text { Marital status } \\
\text { (Ref. Married) }\end{array}$} \\
\hline Divorced/Separated & $\begin{array}{l}1.112 \\
(.366)\end{array}$ & $\begin{array}{l}1.143 \\
(.376)\end{array}$ \\
\hline Widowed & $\begin{array}{l}1.620 \\
(.613) \\
\end{array}$ & $\begin{array}{l}1.682 \\
(.620) \\
\end{array}$ \\
\hline Never Married & $\begin{array}{c}.971 \\
(.400)\end{array}$ & $\begin{array}{l}1.028 \\
(.424)\end{array}$ \\
\hline
\end{tabular}

$* \mathrm{p}<0.05, * * \mathrm{p}<0.01, * * * \mathrm{p}<0.001$. Coefficients are odds ratio. Parenthesis contains standard errors.

Model 4.a: $\mathrm{N}=1596$, Pseudo $\mathrm{R}^{2}=0.0354$

Model 4.b: $\mathrm{N}=1634$. Pseudo $\mathrm{R}^{2}=0.0512$ 


\section{Pain medication}

Model 4.b presents the result of predicting victimization with friend's misuse of prescription pain medication, with self-misuse of prescription pain medication, and with control variables. The odds ratio of 1.314 for peer misuse of prescription pain medication suggests that there is an association between having prescription pain medication misuser friends and the odds of victimization. In the other words, for every one unit change in the frequency of having prescription pain medication misuser friends, there are 1.314 odds of victimization for respondents. This result is statistically significant at $p<0.001$ which evident a strong association between having prescription pain medication misuser friends and victimization. Self-misuse of prescription pain medication variable was controlled for finding this result. Independent of friends' misuse of prescription pain medication, self-misuse of prescription pain medication report odds ratio of 1.094 but the result is not statistically significant. This means while I control friend's misuse, self-misuse does not report predictability of victimization. But while I control self-misuse, friends misuse reports significant predictability of self-victimization. The findings do not support part of our hypothesis 2 that the association between friend's misuse of prescription pain medication and victimization will be mediated through self-misuse of prescription pain medication.

The findings of the gender variable report an odds ratio of 1.872 for males. This means compared to the odds of victimization being female, the odds of victimization being male is $87 \%$ greater. The result is statistically significant at $p<0.05$. Other control measures e.g. age, education level, race and, marital status report no significant odds ratio in the model.

To sum up, the model 4 that includes a and $\mathbf{b}$, I predicted the victimization with peer delinquent behaviors and self-delinquent behavior. I hypothesize that there is an association between having delinquent peers and victimization (hypothesis 1) and the association is mediated through self-delinquency (hypothesis 2). Model 3 is based on only hypothesis 1 and 
model 4 is based on both hypothesis 1 and hypothesis 2 . The result of model 4 (including a and b) supports hypothesis 1 but does not support hypothesis 2 . Independent of self-delinquent behavior, I find an association between having delinquent friends (both marijuana users and prescription pain medication misusers) and victimization. But if friend's delinquent behavior is controlled, I find no association between self-delinquent behavior and victimization. So, it suggests that self-delinquent behavior does not mediate the association between having delinquent friends and victimization for adult population.

\section{Probability graphs for all four models}

Fig 1: Model 1, Predicting Self-delinquency
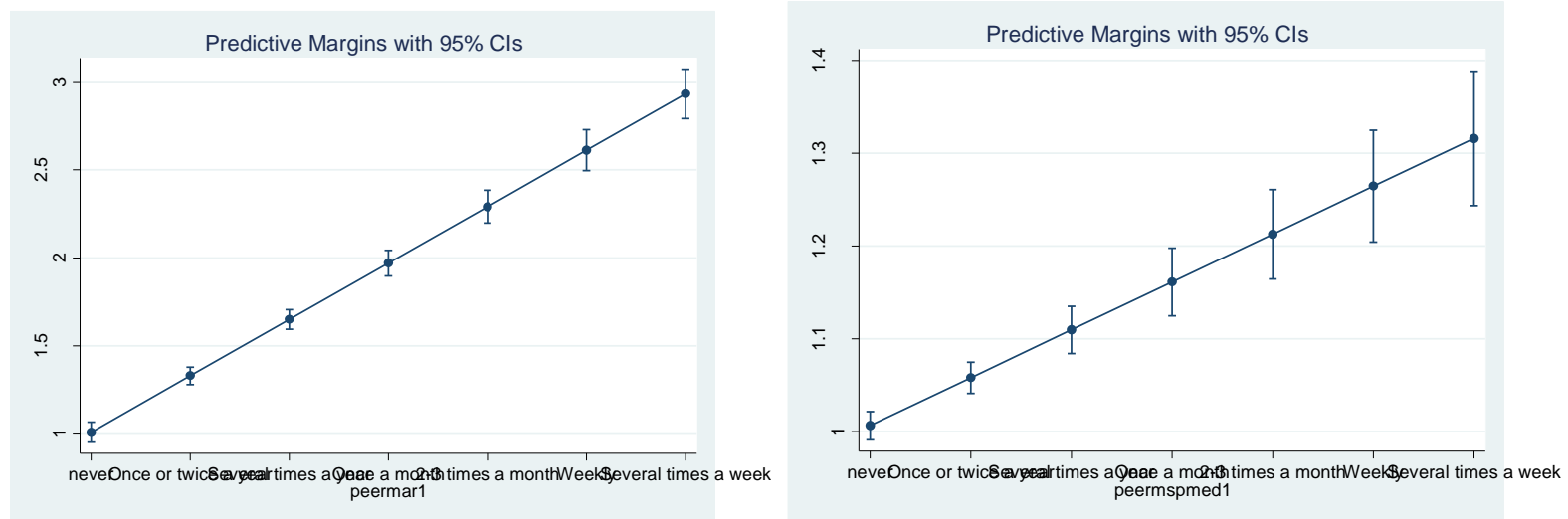

Fig 1.1: Predicting self-marijuana use

Fig 1.2: Predicting self-pain medication misuse

Fig 2: Model 2, Predicting Victimization with Self-delinquency
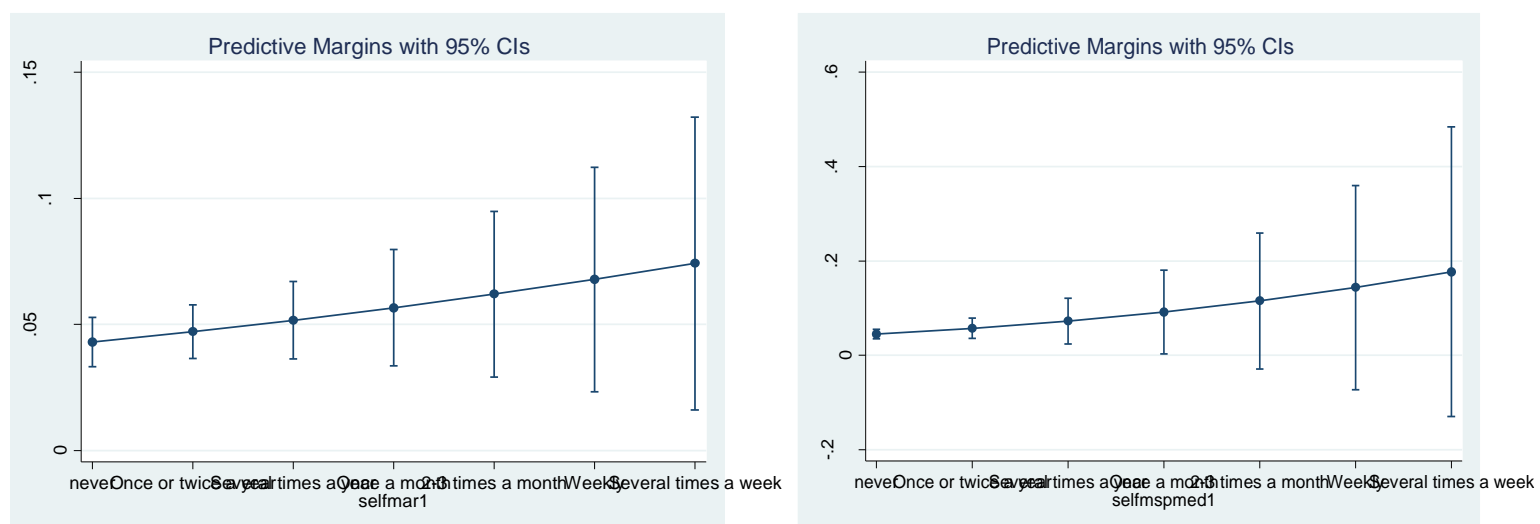

Fig 2.1: Predicting victimization with self-marijuana use Fig 2.2: Predicting victimization 
with self-misuse of pain medication

Fig 3: Model 3, Predicting Victimization with Peer Delinquency
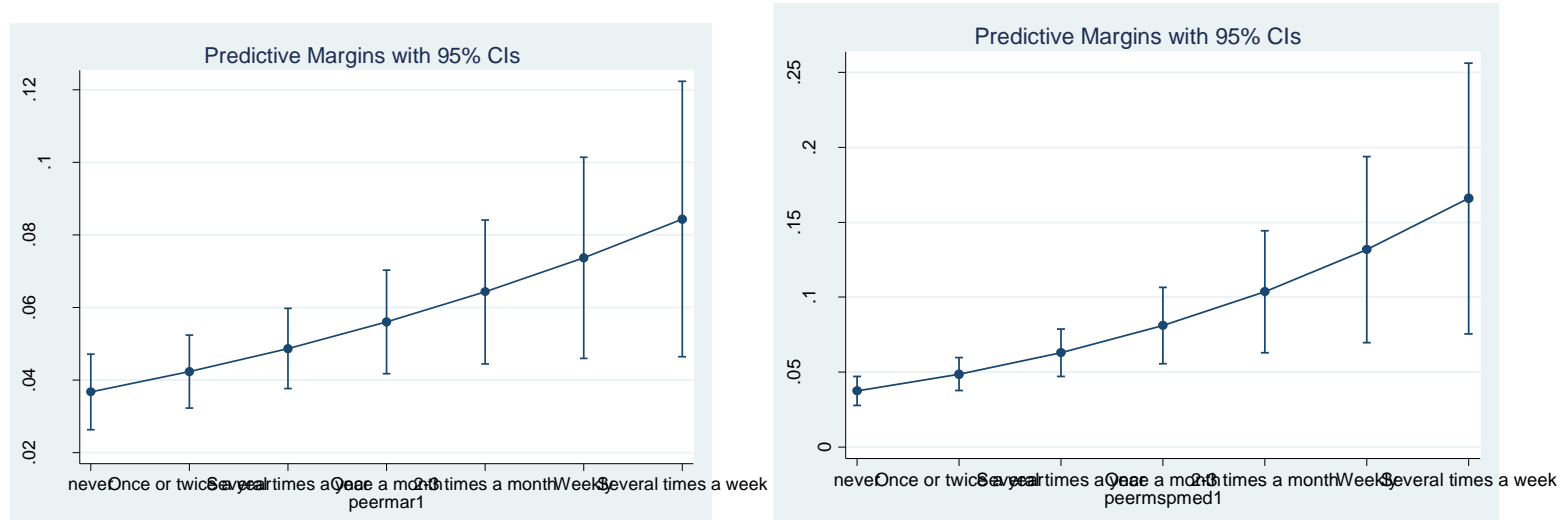

Fig 3.1: Predicting victimization with peer marijuana use Fig 3.2: Predicting victimization with peer pain medication misuse

Fig 4: Model 4, Predicting Victimization with Peer Delinquency and Self-delinquency

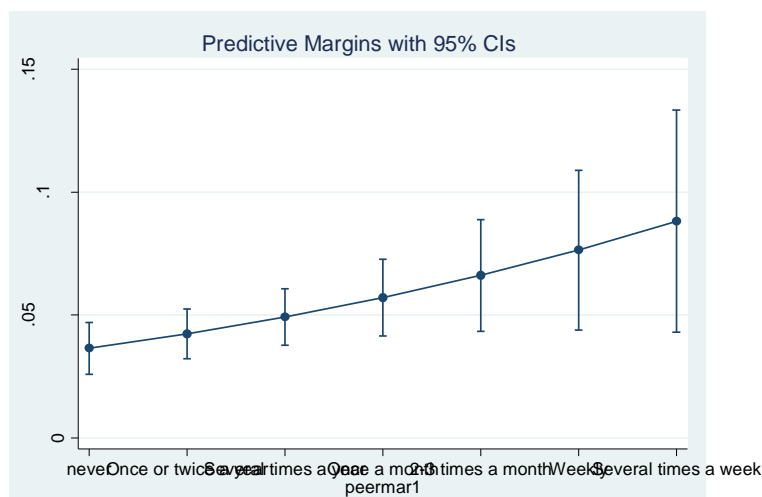
peermar1

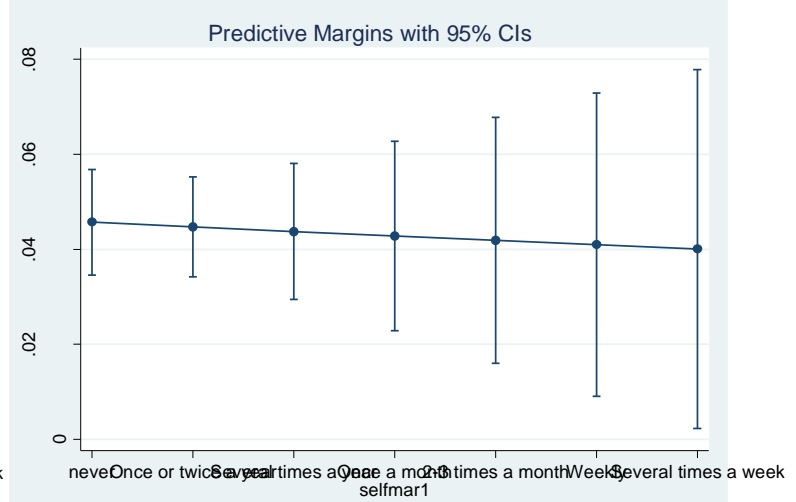

Fig 4.2 victimization with self-marijuana (Not significant) 


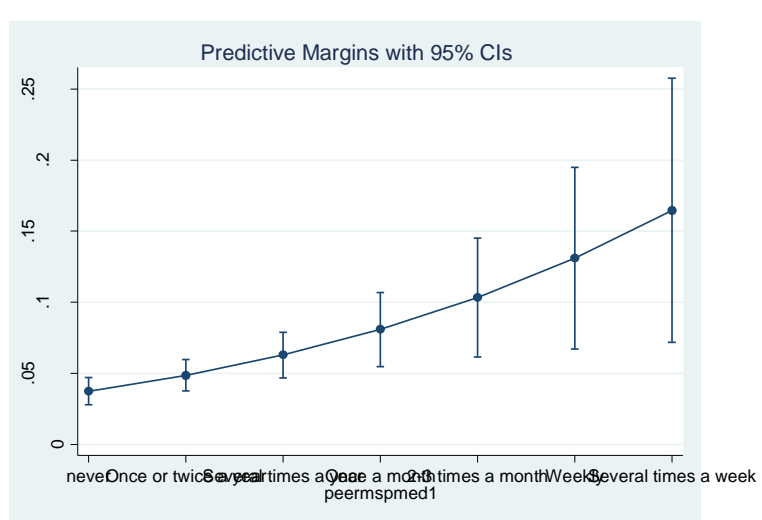

Fig 4.3: victimization with peer pain medication

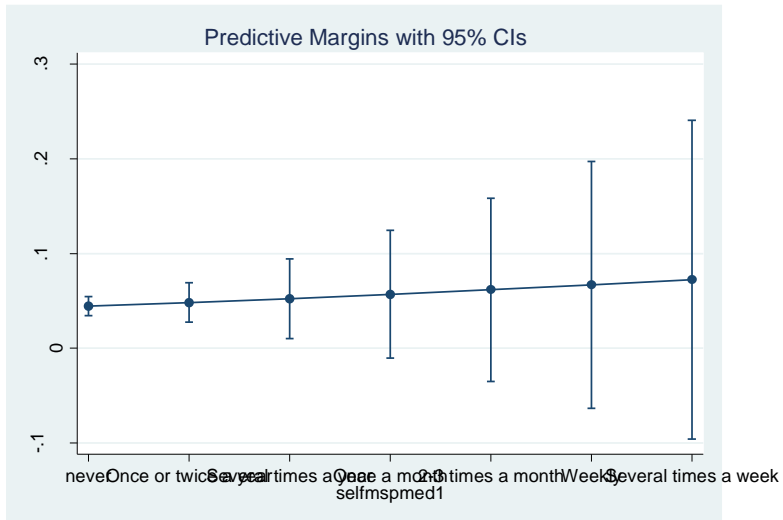

Fig 4.4 Victimization with self-pain

medication (Not significant)

\section{Discussion and Conclusion}

I argued that the third proposition of differential association theory is the basis of this study. Delinquency is learned through the association with delinquent friends. I operationalized the frequency of marijuana use and prescription pain medication misuse as having delinquent friends. I also argued that the characteristics of delinquent friends and victims can be used as reciprocal for both parties. After learning delinquent behavior, a person can become an offender and in return, they will become the victims as well. It is because the first victim of the first offender can attack the first offender in return as an act of revenge, thus the first offender can become the second victim. For our purpose, I used differential association theory to describe learning delinquent behavior and explain victimization due to association with delinquent friends. The analysis of the result indicates that having delinquent friends is associated with learning delinquent behavior. For two delinquent behaviors i.e. marijuana use and prescription pain medication misuse, the result shows a significant association between having marijuana users and prescription pain medication misuser friends and learning of those two delinquent behaviors. 
The analysis of victimization and delinquent behavior suggests that independent of selfdelinquent behavior there is an association between having delinquent friends and selfvictimization. The result founds a similar significant association for two delinquent behaviors i.e. marijuana use and prescription pain medication misuse. These findings support our hypothesis 1 that there is an association between victimization and having delinquent peers. But the hypothesis 2 that is the association is mediated through self-delinquency has not been supported by the findings. Independent of friend's delinquency there is no significant association found between victimization and self-delinquent behavior. So, it can be said that people can be a victim not for self-delinquent behavior rather for having delinquent friends.

This study finds that the theory of differential association can be applied to explain adult delinquency and adult victimization. This theory was originally proposed to describe adolescent delinquency and a lot of subsequent tests have been conducted on the adolescent population as well. So, the finding of this study can be a contribution to the study of the applicability of the theory of the differential association on the adult population. In this study, the result finds that having adult delinquent friends are associated with learning delinquent behaviors especially marijuana use and prescription pain medication misuse. Moreover, marital status is determining the condition of learning delinquent behaviors. The result shows that never married persons compared to married persons having adult delinquent friends tend to learn delinquent behaviors. I assume that singlehood in personal life may encourage them to hang out with delinquent friends which leads them to use marijuana and prescription pain medication misuse. As married persons report opposite results of never married persons, there is the scope of study from social bond and loneliness perspectives. Future studies can search for answers to the question that, does loneliness encourage to hang out with adult delinquent friends? or social bond i.e. married to another can deter oneself to hang out with adult delinquent friends? 
In predicting self-delinquency with peer delinquency, the result shows that there is an association between having delinquent friends and involving in delinquent behaviors. Both marijuana use and prescription pain medication misuse predict the same results. In that case, the third proposition of differential association theory has been supported by the data I used. That is learning delinquent behavior through group interaction is found truthful in our analysis especially on the adult population.

I primarily argued that victimization is associated with having delinquent friends for the adult population. I measured victimization with the frequency of having delinquent friends and found that there is a significant association between them. The result shows that the more the number of delinquent friends the more the probability of victimization. Marijuana user friends and pain medication misuser friends report a significant difference in the prediction of victimization. Having marijuana user friends predicts a maximum of around $9 \%$ of victimization, while having pain medication misuser friends predicts a maximum of approximately $17 \%$ of victimization.

Another argument I made is that with differential association theory, I predicted victimization for having delinquent friends will be mediated through self-delinquent behavior. That means, if self-delinquency is controlled, there will be no association between victimization and having delinquent friends. Model 4 findings do not support this argument, while controlling self-delinquent behavior, there is still an association between victimization and having delinquent friends. So, hypothesis 2 is not supported in the study. The possible reason for this outcome is maybe using the theory on the adult population. The theory is dominantly used on the adolescent population, but I used it on the adult population. This also can be another limitation of the study. 
The study found no gender difference in predicting self-delinquent behavior for having delinquent friends. That means, learning marijuana use and prescription pain medication misuse do not vary in the male-female population. But gender is crucial in predicting victimization for having delinquent friends. Males are reported to be victimized more than females in all models 2, 3 and 4. These findings support hypothesis 3. The reason for this difference is that females are less likely to be involved in delinquent behavior than males. So, the chance of victimization is less for females as well.

In summary, I argue that differential association theory is applicable to study adult delinquency and adult victimization as well beyond the adolescent population. Association with delinquent friends will influence people to learn delinquent behaviors that are practiced by those friends. The study also finds that victimization is associated with having delinquent friends. But the association is not mediated through self-delinquent behavior though I expected otherwise. Gender is not a factor in learning delinquent behavior, but it is crucial in predicting victimization. Males are reported to be victimized more than females.

\section{Reference:}

Agresti, Alan. 2018. Statistical methods for the social sciences. Boston: Pearson education

Akers. Ronald L. 1973. Deviant Behavior: A Social Learning Approach. $1^{\text {st }}$ ed. Belmont, CA: Wadsworth

Anderson, Elijah. 2000. Code of the Street: Decency, Violence, and the Moral Life of the Inner City. W. W. Norton \& Company.

Beaver, Kevin M. 2011. "Environmental Moderators of Genetic Influences on Adolescent Delinquent Involvement and Victimization.” Journal of Adolescent Research 26(1):84-114. doi: 10.1177/0743558410384736. 
Burgess, Robert L., and Ronald L. Akers. 1966. "A Differential Association-Reinforcement Theory of Criminal Behavior.” Social Problems 14(2):128-47. doi: 10.2307/798612.

Cloward, Richard A., and L. E. Ohlin. 2013. Delinquency and Opportunity: A Study of Delinquent Gangs. Routledge.

Cohen, Albert K. 1955. Delinquent Boys; The Culture of the Gang. New York, NY, US: Free Press.

Cressey, Donald R. 1954. "The Differential Association Theory and Compulsive Crimes." The Journal of Criminal Law, Criminology, and Police Science 45(1):29-40. doi: $10.2307 / 1139301$.

Cressey, Donald R. 1960. “The Theory of Differential Association: An Introduction Four Articles on Differential Association." Social Problems 8(1):2-6.

Dull, R. Thomas. 1983. 'Friends' Use and Adult Drug and Drinking Behavior: A Further Test of Differential Association Theory." The Journal of Criminal Law and Criminology (1973-) 74(4):1608. doi: 10.2307/1143067.

Fox, Kathleen A., Matt R. Nobles, and Ronald L. Akers. 2011. "Is Stalking a Learned Phenomenon? An Empirical Test of Social Learning Theory.” Journal of Criminal Justice 39(1):39-47. doi: 10.1016/j.jcrimjus.2010.10.002.

Glaser, Daniel. 1956. “Criminality Theories and Behavioral Images.” American Journal of Sociology 61(5):433-44. doi: 10.1086/221802.

Glaser, Daniel. 1960. "Differential Association and Criminological Prediction Four Articles 
on Differential Association." Social Problems 8(1):6-14.

Gottfredson, Michael R., and Travis Hirschi. 1990. A General Theory of Crime. Stanford University Press.

Gover, Angela R., Catherine Kaukinen, and Kathleen A. Fox. 2008. “The Relationship Between Violence in the Family of Origin and Dating Violence Among College Students." Journal of Interpersonal Violence 23(12):1667-93. doi: 10.1177/0886260508314330.

Haynie, Dana L. 2001. “Delinquent Peers Revisited: Does Network Structure Matter?” American Journal of Sociology 106(4):1013-57. doi: 10.1086/320298.

Hirschi, Travis. 1969. Causes of Delinquency. Berkley: Free Press

Jackson, Elton F., Charles R. Tittle, and Mary Jean Burke. 1986. “Offense-Specific Models of the Differential Association Process*." Social Problems 33(4):335-56. doi: 10.2307/800723.

Jeffrey, Criminal Behavior. 1965. "Learning Theory, 56 J.” CRIM. LC \& PS 294:297.

Jennings, Wesley G., MiRang Park, Elizabeth A. Tomsich, Angela R. Gover, and Ronald L. Akers. 2011. "Assessing the Overlap in Dating Violence Perpetration and Victimization among South Korean College Students: The Influence of Social Learning and Self-Control.” American Journal of Criminal Justice 36(2):188-206. doi: 10.1007/s12103-011-9110-X.

Kauzlarich, David, and Hugh D. Barlow. 2009. Introduction to Criminology. Rowman \& Littlefield. 
Kornhauser, Ruth R. 1963. "Theoretical Issues in the Sociological Study of Juvenile

Delinquency." Unpublished manuscript, Center for the Study of Law and Society, Berkley

Lauritsen, Janet L., Robert J. Sampson, and John H. Laub. 1991. “The Link Between

Offending and Victimization Among Adolescents*." Criminology 29(2):265-92. doi: https://doi.org/10.1111/j.1745-9125.1991.tb01067.x.

Matsueda, Ross L. 1988. "The Current State of Differential Association Theory." Crime \& Delinquency 34(3):277-306. doi: 10.1177/0011128788034003005.

Mears, Daniel P., Matthew Ploeger, and Mark Warr. 1998. "Explaining the Gender Gap in Delinquency: Peer Influence and Moral Evaluations of Behavior.” Journal of Research in Crime and Delinquency 35(3):251-66. doi: 10.1177/0022427898035003001.

Mustaine, Elizabeth Ehrhardt, and Richard Tewksbury. 2000. "Comparing the Lifestyles of Victims, Offenders, and Victim-Offenders: A Routine Activity Theory Assessment of Similarities and Differences for Criminal Incident Participants.” Sociological Focus 33(3):339-62. doi: 10.1080/00380237.2000.10571174.

Rebellon, Cesar J. 2012. "Differential Association and Substance Use: Assessing the Roles of Discriminant Validity, Socialization, and Selection in Traditional Empirical Tests.” European Journal of Criminology 9(1):73-96. doi: 10.1177/1477370811421647.

Schreck, Christopher J. 1999. “Criminal Victimization and Low Self-Control: An Extension and Test of a General Theory of Crime." Justice Quarterly 16(3):633-54. doi: $10.1080 / 07418829900094291$. 
Schreck, Christopher J., Eric A. Stewart, and Bonnie S. Fisher. 2006. "Self-Control, Victimization, and Their Influence on Risky Lifestyles: A Longitudinal Analysis Using Panel Data.” Journal of Quantitative Criminology 22(4):319-40. doi: 10.1007/s10940-006-9014-y.

Schreck, Christopher J., Richard A. Wright, and J. Mitchell Miller. 2002. “A Study of Individual and Situational Antecedents of Violent Victimization.” Justice Quarterly 19(1):159-80. doi: 10.1080/07418820200095201.

Stewart, Eric A., Christopher J. Schreck, and Ronald L. Simons. 2006. “'I Ain’t Gonna Let No One Disrespect Me': Does the Code of the Street Reduce or Increase Violent Victimization among African American Adolescents?" Journal of Research in Crime and Delinquency 43(4):427-58. doi: 10.1177/0022427806292338.

Weinberg, K, S. 1966. "Personality and Method in the Differential Association Theory: Comments on 'A Reformulation of Sutherland's Differential Association Theory and a Strategy for Empirical Verification."” Journal of Research in Crime and Delinquency 3(2):165-72. doi: 10.1177/002242786600300210.

West Virginia University. Survey Research Center, Department of Sociology and Anthropology. 2020. "The 2020 West Virginia Social Survey (WVSS)" Zavala, Egbert, Ryan E. Spohn, and Leanne F. Alarid. 2019. "Gender and Serious Youth Victimization: Assessing the Generality of Self-Control, Differential Association, and Social Bonding Theories." Sociological Spectrum 39(1):53-69. doi: 10.1080/02732173.2019.1608341. 